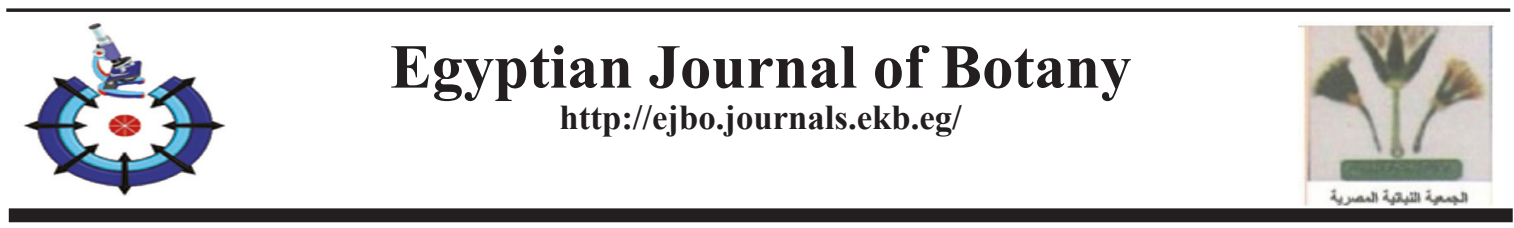

\title{
Assessment of the Optimum Growth Medium and the Effect of Different Light Intensities on Growth and Photosynthetic Pigments of Chlorella vulgaris and Scenedesmus arvernensis
}

\author{
Mostafa M. El-sheekh ${ }^{(1) \#}$, Hanaa H. Morsi ${ }^{(2)}$, Lamiaa H.S. Hassan ${ }^{(2)}$ \\ (1)Botany Department, Faculty of Science, Tanta University, Tanta, Egypt; (2)Botany \\ and Microbiology Department, Faculty of Science, Menoufia University, Menoufia, \\ Egypt.
}

\begin{abstract}
HHORELLA vulgaris and Scenedesmus arvernensis are common eukaryotic green microalgae that have a very wide use in various applications. They can be used as raw materials in bio-energy production, in aquaculture nutrition, in pharmaceuticals, cosmetics, biofertilizers, biodegradation of wastes and dyes. So, this required several studies to test some factors that can influence the growth rate and evaluate their yield. This study investigated the effects of different media compositions: Bold's basal medium, BG-11 medium, modified Chu10 medium, and Kuhl's medium on growth of $C$. vulgaris and S. arvernensis. Then, study the effect of four different light intensities on the growth rate using the optimized medium. The growth was recorded by estimating optical density (OD), cell counting (CC) and total chlorophyll contents. The results showed that the maximum growth was recorded at Modified CHU's 10 medium for $C$. vulgaris and BG-11 medium for $S$. arvernensis. The growth was compared with the initial record of $C$. vulgaris and $S$. arvernensis inocula; the OD increased by 6.85 and 5.15 times, respectively. C. vulgaris showed the optimum CC 9.60 times and total chlorophyll 7.96 times. CC recorded 10.42 times and total chlorophyll increased 5.90 times for $S$. arvernensis. Light intensities experiment showed that $C$. vulgaris gave the best growth rate at $60 \mu \mathrm{mol}$ photons $\mathrm{m}^{-2} \mathrm{~s}^{-1}$, on the $35^{\text {th }}$ day of cultivation with increasing in $\mathrm{OD}, \mathrm{CC}$ and total chlorophyll, $(6.18,5.27$ and 3.58 times), of the initial record, respectively. Concerning $S$. arvernensis optimum growth rate was reached at $40 \mu \mathrm{mol}$ photons $\mathrm{m}^{-2} \mathrm{~s}^{-1}$, on the $35^{\text {th }}$ day accompanied by an increment in OD, CC and total chlorophyll, (6.20, 4.55 and 10.04 times), of the initial record, respectively.
\end{abstract}

Keywords : Biomass, Chlorella vulgaris, Green algae, Growth media, Growth optimization, Light intensity, Light source, Microalgae, Scenedesmus arvernensis.

\section{Introduction}

Algae are a diverse group of photosynthetic organisms. They are classified to microalgae and macroalgae, they are present in aquatic and terrestrial ecosystems. Microalgae are microscopic organisms, including a huge variety of species. Microalgae require three main components for their growth including sunlight, nutrients from the water, and carbon source such as $\mathrm{CO}_{2}$ from the air, they release about $50 \%$ of the atmospheric oxygen (Nigam \& Singh, 2011).
Nowadays, there is a wide field of applications which depends on microalgae. They can produce valuable materials including carotenoids, lipid, natural dye, polyunsaturated fatty acid, peptide, toxin, sterols, phenolic compounds, immune modulators, agars, agarose, alginates, carrageenans and vitamin B (Wen \& Chen, 2003; He et al., 2005). They can be used for aquaculture feeds, animal, human nutrition supplements, pharmaceuticals, cosmetic products, pigments and biofertilizer. They can be used for extracting high-value molecules, stable isotope

\#Corresponding author email: mostafaelsheikh@science.tanta.edu.eg

Received 15/10/2019; Accepted 18/12/2019

DOI: $10.21608 /$ ejbo.2019.18274.1367

Edited by: Prof. Dr. Salama A. Ouf, Faculty of Science, Cairo University, Giza 12613, Egypt.

(C)2020 National Information and Documentation Center (NIDOC) 
biochemicals, (Pulz \& Grass, 2004; MorenoGarcia et al., 2017). Algae are available biomass for bio-energy fuel (bioethanol and biodiesel) due to their rapid growth rate and productivity (Li et al., 2008; Abou-El-Souod et al., 2017) and high oil content (oil yield in microalgae can exceed $75 \%$ by weight of dry biomass (Christi, 2007; Hu et al., 2008). Algae are used in wastewater treatment and dyes degradation from inorganic salts, such $\mathrm{NH}^{4+}$, $\mathrm{NO}^{3-}, \mathrm{PO}_{4}^{3-}$, using them as nutrient materials (Mata et al., 2010; Makarevičienè et al., 2011; Suganya et al., 2016; Moreno-Garcia et al., 2017; El-Sheekh et al., 2018).

Several researchers studied how to maximize the growth rate (GR) of microalgae. The growth of microalgae depended on the type of microalgae, the $\mathrm{CO}_{2}$ rate, light intensity, temperature, $\mathrm{pH}$, nutrient constituents and dark-light period (Welter et al., 2013; Zhao \& Su, 2014; Han et al., 2015; Cheah et al., 2018; Derakhshandeh \& Tezcan Un, 2019).

Both $C$. vulgaris and $S$. arvernensis are green microalgae, in the class Chlorophyceae. They are considered to be a valuable microalgae for several applications because they have a high growth rate, (Gouveia \& Oliveira, 2009; Yoo et al., 2010).

This study aimed to evaluate the growth of $C$. vulgaris and $S$. arvernensis by using different media compositions and study the effect of different light intensities on the growth at the optimum growth conditions.

\section{Material and Methods}

\section{Algal strains}

The experimental organism Chlorella vulgaris was obtained from Phycology laboratory, Faculty of Science, Menoufia University, Egypt. While, $S$. arvernensis, was isolated from fresh water canals in Shebin El-kom, Menoufia government, Egypt. The purified isolated microalga was identified up to species level using an inverted divert light microscope following the keys of identifications (Bold \& Wynne, 1978; Prescott, 1984; Yamagishi, 1992; Vymazal, 1995).

\section{Algae cultivation media}

C. vulgaris and $S$. arvernensis were grown on four synthetic media with adjusted $\mathrm{pH}(7 \pm 0.2)$, to check the optimized medium that gives the best growth, Bold's basal medium (Bischoff \& Bold, 1963), BG-11 Medium (Ilavarasi et al., 2011),
Modified Chu-10 medium (Stein, 1973), and Kuhl's medium (Kuhl \& Lorenzen, 1964).

For each species, $250 \mathrm{ml}$ conical flasks were prepared, each one containing $90 \mathrm{ml}$ of each medium. The $\mathrm{pH}$ for each medium was adjusted with $1 \mathrm{M}$ sodium hydroxide $(\mathrm{NaOH})$ and $1 \mathrm{~N}$ hydrochloric acid $(\mathrm{HCl})$ by using $\mathrm{pH}$ meter (SCHOTT CG 843). Before experimental setup the media were sterilized in autoclave at $121^{\circ} \mathrm{C}, 1.5 \mathrm{~atm}$. for $20 \mathrm{~min}$. The autoclaved media were inoculated uniformly with $10 \%(\mathrm{v} / \mathrm{v})$ microalgal cell suspension. The flasks were attached with air pumps and incubated at $25 \pm 3^{\circ} \mathrm{C}$ under continuous illumination of three standard cool white LED lamps $(9 \mathrm{~W})(60 \mu \mathrm{mol}$ photons $\left.\mathrm{m}^{-2} \mathrm{~s}^{-1}\right)$. This experiment was carried out in three replicates. The growth was observed using optical density (OD), cell count (CC) and chlorophyll contents (Chl. Cont.). The growth curve was followed up for 6 weeks.

\section{Light intensities}

According to Abou-El-Souod et al. (2016), the effect of light sources was tested to cultivate the $C$. vulgaris and $S$. arvernensis, using sunlight and artificial illumination provided from white Led lamps. Four growth sets were constructed and illuminated by white Led lamps, which were mounted in the chamber at a height of about $30 \mathrm{~cm}$ from the bench top:

(i) The $1^{\text {st }}$ Set: Illumination by Sunlight $(125 \mu \mathrm{mol}$ photons $\mathrm{m}^{-2} \mathrm{~s}^{-1}$ ),

(ii) The $2^{\text {nd }}$ Set: Illuminated by one white Led lamp $\left(25 \mu \mathrm{mol}\right.$ photons $\left.\mathrm{m}^{-2} \mathrm{~s}^{-1}\right)$,

(iii) The $3^{\text {rd }}$ Set: Illuminated by two white Led lamps $\left(40 \mu \mathrm{mol}\right.$ photons $\left.\mathrm{m}^{-2} \mathrm{~s}^{-1}\right)$ and

(iv) The $4^{\text {th }}$ Set: Illuminated by three white Led lamps $\left(60 \mu \mathrm{mol}\right.$ photons $\left.\mathrm{m}^{-2} \mathrm{~s}^{-1}\right)$.

Each set consisted of three $250 \mathrm{ml}$ Elementary flasks, each flask contained $90 \mathrm{ml}$ sterilized modified CHU's-10 medium for C. vulgaris and BG-11 medium for $S$. arvernensis which were inoculated by $10 \%$ of each algal species.

Optical density (OD)

According to (Sharma et al., 2011; AbouEl-Souod et al., 2016; Weise et al., 2019), OD is represented in terms of absorption using colorimeter at $680 \mathrm{~nm}$ by spectrophotometry (Spectro UV-VIS DUAL BEAM 8 AUTO CELL UVS-2700, Germany). 


\section{Cell count (CC)}

According to (Abou-El-Souod et al., 2016; Loftus \& Johnson, 2019), depending on the size of the alga, and whether the algae are single celled and not colonial or chain-forming. Cell numbers can be determined using a Neubauer haemocytometer (Guillard \& Sieracki, 2005) or Sedgwick-Rafter chamber (McAlice, 1971). The haemocytometer is the most widely used for cell counting around the world. It is suitable for cells in the size range of blood cells (i.e. less than about $100 \mu \mathrm{m}$ in diameter) and for cell densities less than $10^{5}$ cells. $\mathrm{ml}^{-1}$. The number of cells is the summation of all the counted cells in all squares counted. The volume is the total volume of all the squares counted. The formula used when counting in the big squares. Errors in the range of $20 \%$ $30 \%$ are common in this method due to pipetting errors, statistical errors, chamber volume errors and errors from volume of simple introduced into the chamber.

Concentration $($ cells $/ \mathrm{ml})=($ Number of cells $\mathrm{x}$ 10.000)/ (Number of squares $x$ dilution).

Extraction and estimation of photosynthetic pigment (Chlorophyll) (Mackinney, 1941)

A known volume of algal cultures $(5 \mathrm{ml})$ was centrifuged at $4000 \mathrm{rpm}$ for $10 \mathrm{~min}$. The pellets were washed twice with distilled water. Add $5 \mathrm{ml}$ of $95 \%$ methanol, then heat on water bath at $60^{\circ} \mathrm{C}$ for $30-60 \mathrm{~min}$. The extracted samples were centrifuged at $4000 \mathrm{rpm}$ for $10 \mathrm{~min}$. The extraction step may be repeated twice to get the complete extraction. The extracts of total chlorophyll were estimated by UV-VIS spectroscopy. Chlorophyll content of the algae was estimated by Spectrophotometry at 650 and $665 \mathrm{~nm}$.

The concentration of chlorophyll was calculated using the formula:

Total chlorophyll $\left(\mathrm{mg} \cdot \mathrm{ml}^{-1}\right)=\left(\left(2.55 \times 10^{-2} \mathrm{E} 650\right)\right.$ $\left.+\left(0.4 \times 10^{-2} \mathrm{E} 665\right)\right) \times 10^{3}$.

\section{Statistical approach}

The results were presented as the mean of three replicates \pm standard deviation (SD). The statistical analyses were carried out using SPSS for Windows (SPSS 16). Data obtained were analyzed statistically to determine least significant difference (LSD) at $5 \%$ probability $(\mathrm{P} \leq 0.05)$ using one way analysis of variance (ANOVA).

\section{Results}

The results showed that the highest growth of C. vulgaris was detected at modified CHU's- 10 medium, on the $35^{\text {th }}$ day. As shown in Figs. 1, 2 and 3 , the optical density (OD), cell count (CC) and total chlorophyll contents were increased by $6.85,9.59$ and 5.90 times compared with the initial record, respectively. While BG-11 medium recorded an enhancement of 6.69 in OD, 9.03 in $\mathrm{CC}$ and 5.61 times in total chlorophyll. The growth of C. vulgaris in Bold's basal medium and Kuhl's medium showed lower increment in all growth parameters on the $28^{\text {th }}$ day.

The results of $S$. arvernensis showed that the maximum growth was detected in BG-11 medium, on the $35^{\text {th }}$ day. As recorded in Figs. 1,2 and 3, the optical density (OD), cell count (CC) and total chlorophyll contents increased by $5.15,10.42$ and 5.90 times, respectively. While modified CHU's-10 medium recorded lower values (4.51 in OD, 8.93 in $\mathrm{CC}$ and 5.61 times total chlorophyll). The growth in Kuhl's medium and Bold's basal medium gave the lower growth rate in all the investigated parameters.

C. vulgaris was grown in the optimized modified CHU's-10 medium and $S$. arvernensis was grown in the optimized BG-11 medium under different light sources (natural and artificial) and intensities. Figures 4, 5 and 6 showed the estimated results.

The highest growth of $C$. vulgaris was obtained at $60 \mu \mathrm{mol}$ photons $\mathrm{m}^{-2} \mathrm{~s}^{-1}$, on the $35^{\text {th }}$ day of the growth, with increasing in OD, CC and total chlorophyll, $6.18,5.27$ and 3.58 times, of the initial record, respectively. While the growth rate showed a parallel decrease with decrasing light intensities of 40 and $25 \mu \mathrm{mol}$ photons $\mathrm{m}^{-2} \mathrm{~s}^{-1}$. The growth estimation at natural Sun light was 4.32 times in OD, 2.95 times in CC and 5.00 times total chlorophyll on the $42^{\text {th }}$ day. The minimum growth rate was detected at $25 \mu \mathrm{mol}$ photons $\mathrm{m}^{-2} \mathrm{~s}^{-1}$, which was recorded (3.03, 2.38 and 1.61 times in OD, $\mathrm{CC}$ and total chlorophyll).

S. arvernensis maximum growth was obtained at light intensity of $40 \mu \mathrm{mol}$ photons $\mathrm{m}^{-2} \mathrm{~s}^{-1}$, in the $35^{\text {th }}$ day of the growth, with increasing in OD, $\mathrm{CC}$ and total chlorophyll, 6.20, 4.54 and 10.04 times, of the initial record, respectively. While the growth curve showed some retardation at $60 \mu \mathrm{mol}$ 
photons $\mathrm{m}^{-2} \mathrm{~s}^{-1}$ on the $28^{\text {th }}$ day, (4.77 times in OD, 2.59 times in $\mathrm{CC}$ and 4.75 times total chlorophyll). While, the growth estimation at natural Sun light was 4.71 times in OD, 2.44 times in CC and 5.00 times total chlorophyll. The minimum growth rate was detected at the lowest intensity of $25 \mu \mathrm{mol}$ photons $\mathrm{m}^{-2} \mathrm{~s}^{-1}$, which recorded 3.86 in $\mathrm{OD}, 2.36$ in $\mathrm{CC}$ and 4.81 times total chlorophyll.

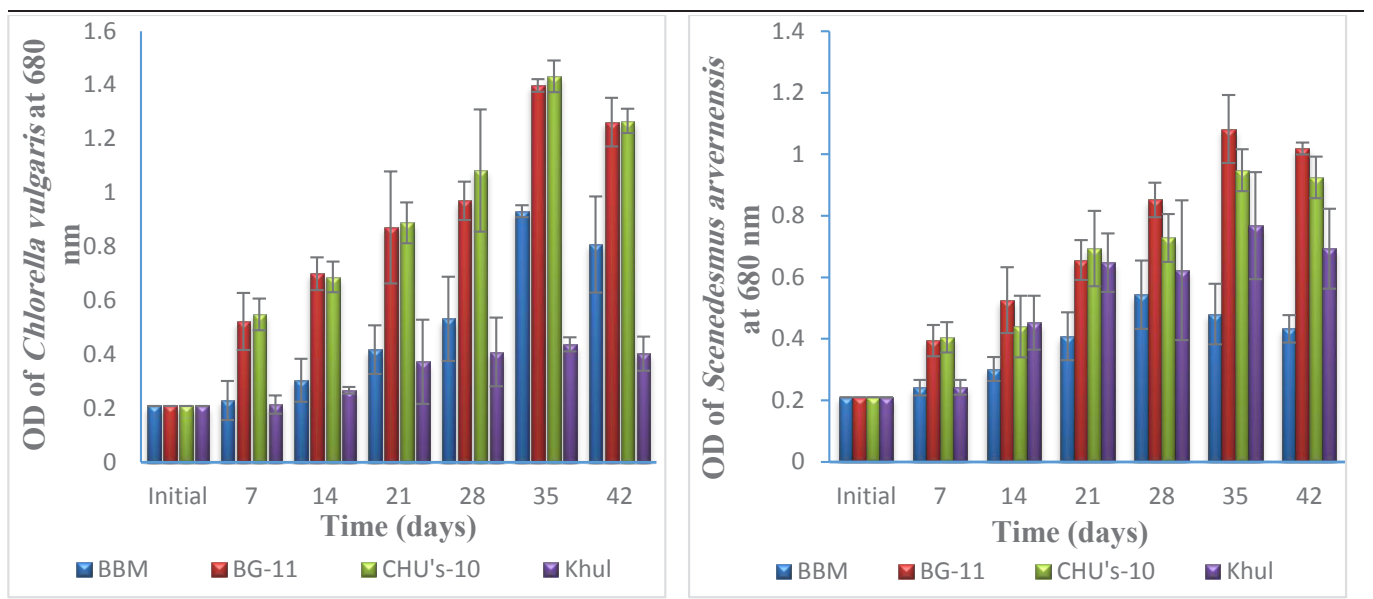

Fig. 1. Effect of different media on growth of $C$. vulgaris and $S$. arvernensis as (OD).
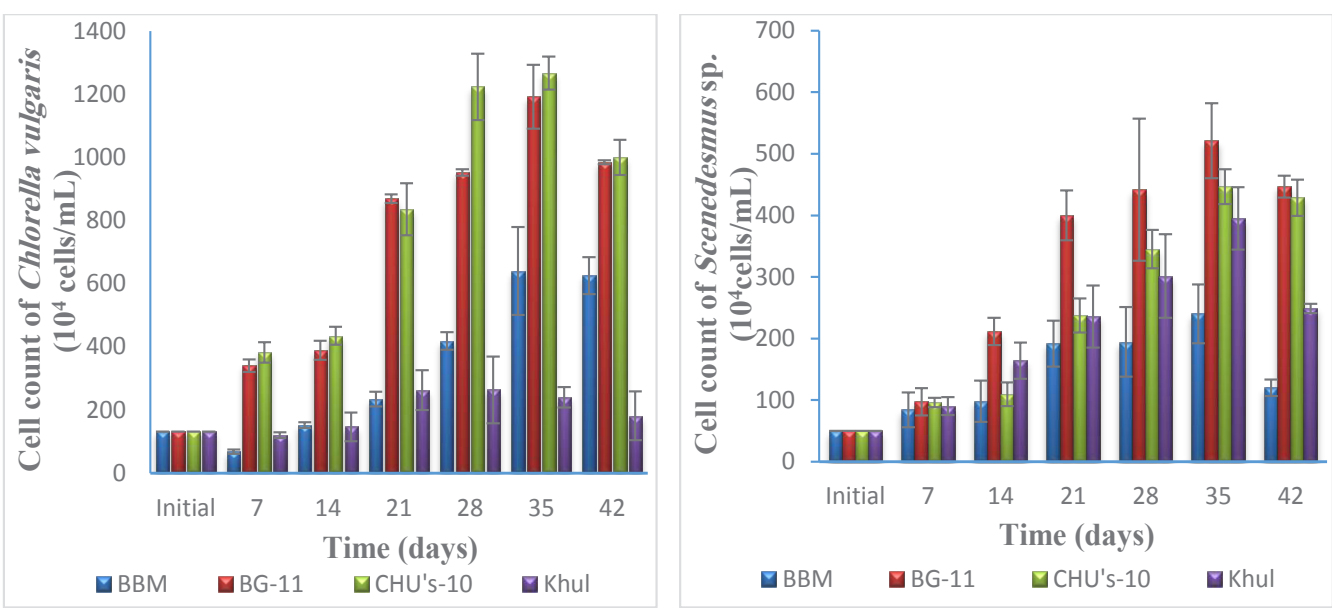

Fig. 2. Effect of different media on growth of $C$. vulgaris and $S$. arvernensis as (CC).

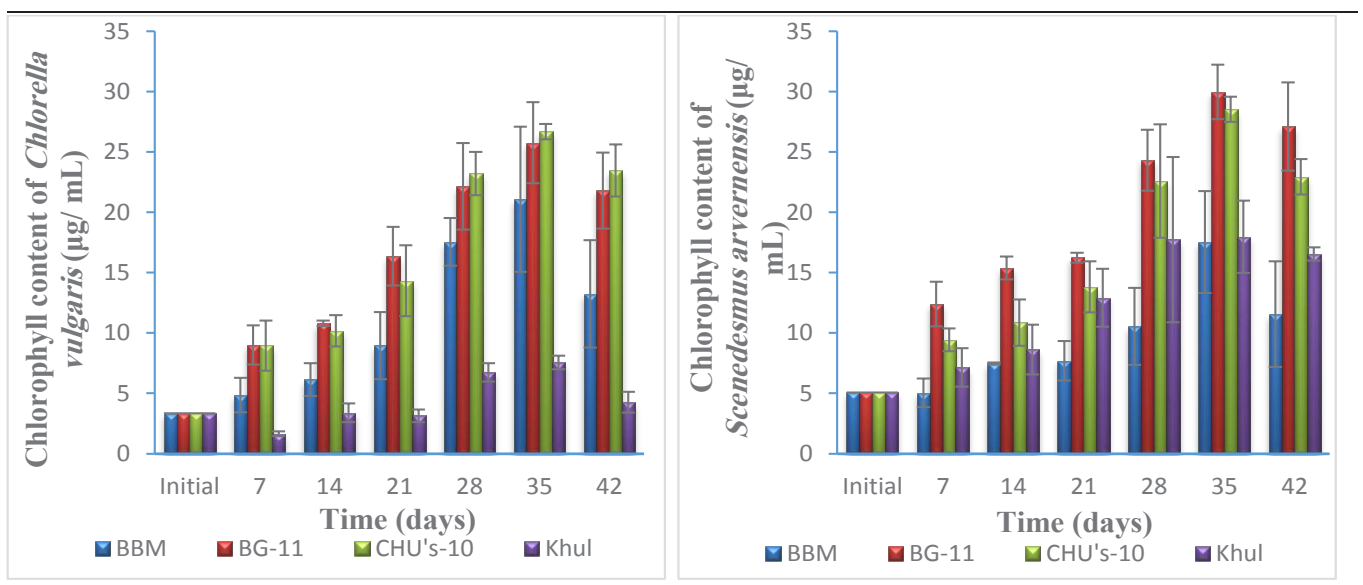

Fig. 3. Effect of different media on growth of $C$. vulgaris and S. arvernensis as (Chl. content). 


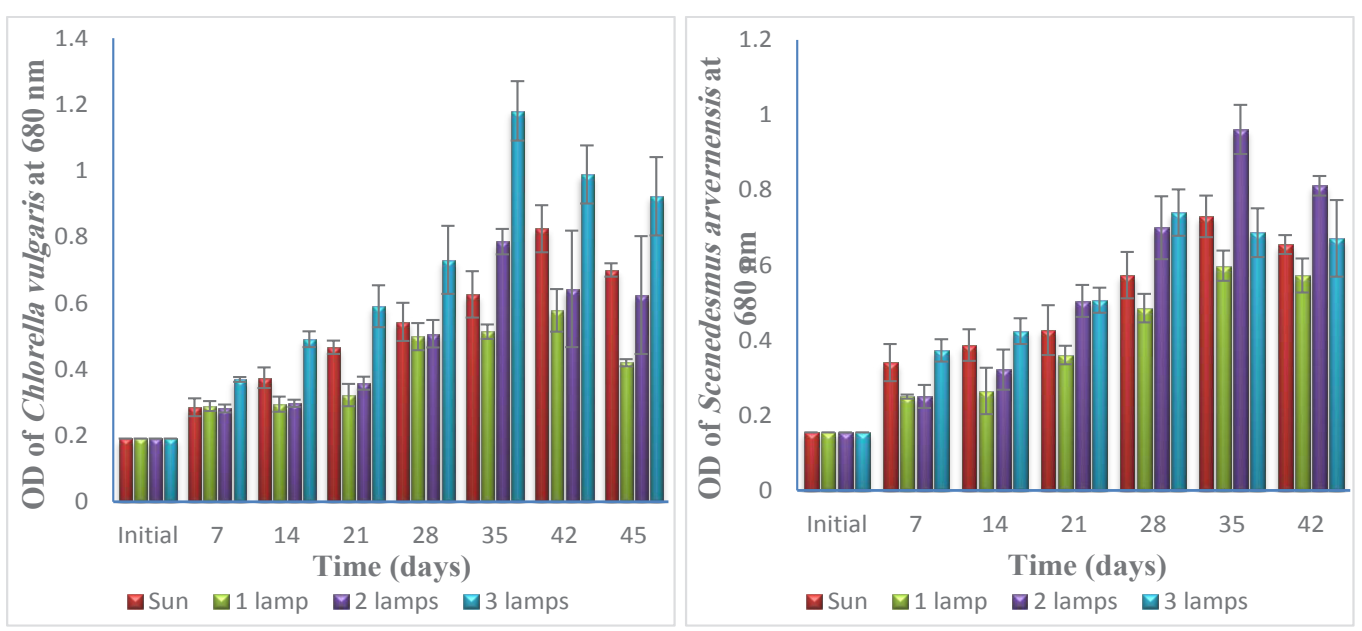

Fig. 4. Effect of different Light Sources of algal culture on growth (OD) of $C$. vulgaris and $S$. arvernensis.

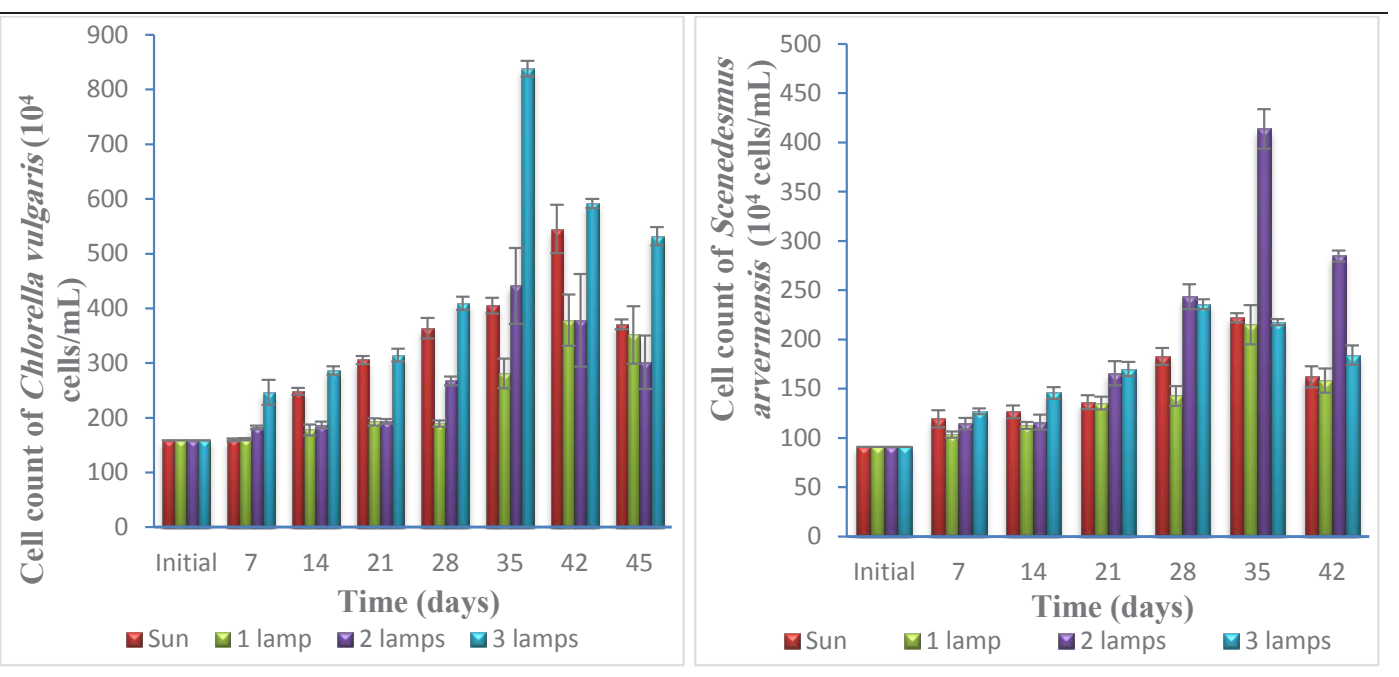

Fig. 5. Effect of different Light Sources of algal culture on growth (cell count $\mathrm{CC}$ ) of $C$. vulgaris and S. arvernensis.

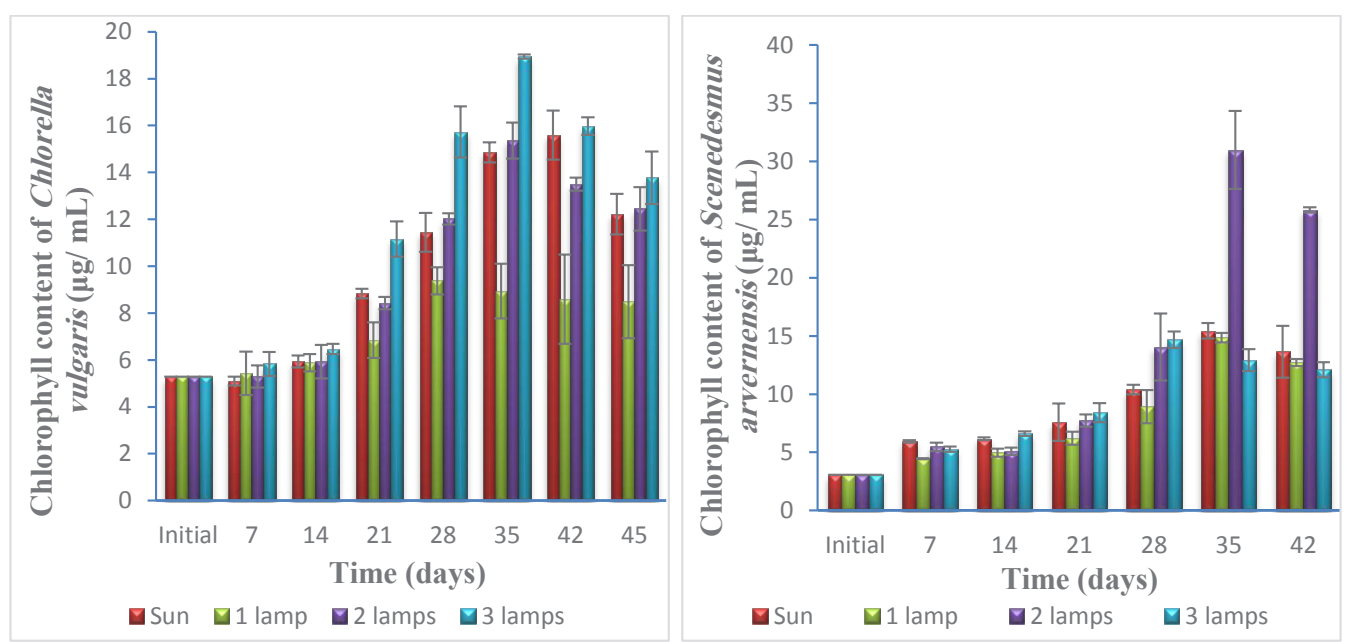

Fig. 6. Effect of different Light Sources of algal culture on growth total Chlorophyll content of C. vulgaris and $S$. arvernensis. 


\section{Discussion}

The results showed that modified CHU's- 10 medium is the optimum medium for C. vulgaris cultivation. This agree with the results reported by Sharma et al. (2011) and Abou El-Souod et al. (2016) who reported that modified CHU's-10 was the best growth medium for $C$. vulgaris cultivation. Kuhl medium was the best growth medium for $C$. vulgaris cultivation according to El-Sheekh et al., 2018. While the maximum biomass productivity of $S$. arvernensis grown in BG-11 medium, compared to other tested media, this agree with El-Naggar \& El-Sheekh (1998), Hamouda et al. (2016), Ruen-ngam (2017), Derakhshandeh \& Tezcan Un (2019). This disagree with Abomohra et al. (2018) who reported that Kuhl medium gave the highest growth for Scenedesmus sp. All algae can do photosynthesis, as they can use natural sun light, atmospheric carbon dioxide $\mathrm{CO}_{2}$ and nutrients. Some elements as macro-elements (N, $\mathrm{P}$, and $\mathrm{O}$ ) other microelements $(\mathrm{Cl}, \mathrm{S}, \mathrm{Mg}, \mathrm{Na}, \mathrm{Ca}$ and $\mathrm{K}$ ) and trace metals from the environment. The higher biomass productivity of each microalgal species in the specific medium might be related to presence of certain components and their concentrations, comparing with the other media components, which are an essential constituents of all structural and functional components of the algal cells (Chu et al., 2007; El-Sheekh et al., 2012).

The results showed that the highest growth of C. vulgaris and S. arvernensis were obtained after cultivation under light intensity of $60 \mu \mathrm{mol}$ photons $\mathrm{m}^{-2} \mathrm{~s}^{-1}$ and $40 \mu \mathrm{mol}$ photons $\mathrm{m}^{-2} \mathrm{~s}^{-1}$, respectively. Sharma et al. (2012) reported that maximum biomass was observed at natural day light. This agree with Richmond \& Grobbelaar (1986), they reported that the growth of the microalgae under laboratory conditions were significantly lower than the growth under natural conditions, which could be explained as artificial illumination caused stress to the cultivated microalgae. Different light sources may cause changes in the microalgal cell properties and photosynthetic efficiency according to the light availability (Dubinsky et al., 1995). Sunlight has equal amount of all the wavelengths, while artificial light consists of a few preferred wavelengths (Rocha et al., 2003; Mercado et al., 2004). Senger \& Fleischhacker (2006) observed that in the low light conditions chlorophyll content was doubled to improve the capture of more light and recover the loss of absorbable wavelengths.
However, the photosynthetic capacity increase three folds at strong light intensity, the chlorophyll contents decrease. Microalgae require light energy to convert carbon dioxide to organic compounds, Juneja et al. (2013), who reported that algal cells can do adaptation with light intensities. They may produce different types and quantities of pigments or the production of fatty acids. Photo-inhibition occurs when light intensity increase above saturating limits (You \& Barnett, 2004). As the high light intensity cause damage in the chloroplast lamellae and inhibit enzymes of carbon dioxide fixation (Iqbal \& Zafar, 1993), they also observed that low light intensity increased protein content while high light intensity enhanced extracellular polysaccharide content. Wahidin et al. (2013) reported that microalgae growth increased at an intensity greater than $50 \mu \mathrm{mol}$ photons $\mathrm{m}^{-2} \mathrm{~s}^{-1}$ but the growth decreased at intensities higher than $200 \mu \mathrm{mol}$ photons $\mathrm{m}^{-2} \mathrm{~s}^{-1}$. Bohutskyi et al. (2016) showed that intensities lower than $30 \mu \mathrm{mol}$ photons $\mathrm{m}^{-2} \mathrm{~s}^{-1}$ produced inefficient growth.

Sunlight or artificial light represent the essential light source for phototrophic algal cells. Lee et al. (1999) reported that the photosynthetic activity of microalgal cells increases with light intensity until reaching the light saturation point. Intensities higher than this point cause damage of the light receptors in the chloroplasts of the cells. This leads to photo inhibition and decrease the photosynthetic rate. The high cell density culture suffers from mutual shading problem, as the cells closest to the surface of the broth culture receive the majority of the available light more than the cells below. There are other parameters affect light distribution, such as the depth of the cultivated media and mixing play key roles (Grobbelaar, 1994). Light affects the physiological process in microalgae (He et al., 2015). As light intensity can regulate the quantity and quality of the available light energy for microalgae that conduct photosynthesis, vital activities and control the metabolic pathway (Khalid et al., 2019).

Makarevičiene et al. (2011) reported that the cultivation of Chlorella sp. and Scenedesmus sp., on BG11 medium in the laboratory required 29 to 50 days. The cultivation of Spirulina take about 40 days in a 1000 L- photobioreactor (Delrue et al., 2017). This long growth incubation period influenced the growth by increasing the biomass. The initial density of inocula affect the duration of growth period. According to Van- 
Khanh et al. (2017) the lowest initial density of the microalgal inoculum required long cultivation time comparing with the highest initial density to reach the highest growth rate.

\section{Conclusion}

The growth of microalgae can be affected by various factors, including different growth media with variable nutrient composition and different $\mathrm{pH}$ values. There are other environmental factors influence the growth, such as light sources, light intensities, temperature, light duration and aeration. As a result of this study; it was concluded that modified CHU's-10 medium was the best medium for C. vulgaris cultivation, and the best light intensity for its growth was $60 \mu \mathrm{mol}$ photons $\mathrm{m}^{-2} \mathrm{~s}^{-1}$. While, BG-11 medium at $\mathrm{pH} 7$ was the optimum medium for $S$. arvernensis growth, in addition to this, light intensity of $40 \mu \mathrm{mol}$ photons $\mathrm{m}^{-2} \mathrm{~s}^{-1}$ (emitted from two white Led lamps) increased the growth and gave the highest growth rate more than the other intensities.

Acknowledgements: The authors thank the Botany and Microbiology Department, Faculty of Science, Menoufia University, for supporting this work.

\section{References}

Abomohra, A.I., Abo-Shady, A.M., Abd El-Moneim, A.M., Khairy, H.M., Marey, R.S. (2018) Effect of different culture media on the growth and lipids of the green microalgae, Scenedesmus obliquus and Micractinium reisseri as a feedstock for biodiesel production. Delta Journal of Science, 3, 176-182.

Abou-El-Souod, G.W., Morsy, E.M., Hassan, L.H.S. (2016) Comparison of different media formulations and the optimal growing conditions on growth, morphology and chlorophyll content of green alga, Chlorella vulgaris. Journal of American Science, 12(6), 86-95.

Abou-El-Souod, G.W., Morsy, E.M., Hassan, L.H.S. (2017) Product ion of Bioethanol from microalga (Chlorella vulgaris). Journal of the Egyptian Society of Experimental Biology, 13(1), 49-54.

Bischoff, H.W., Bold, H.C. (1963) "Phycological Studies IV. Some Soil Algae from Enchanted Rock and Related Algal Species". University of Texas Publications, 6318, pp. 1-95.
Bohutskyi, P., Kligerman, D.C., Byers, N., Nasr, L.K., Cua, C., Chow, S., Su, C., Tang, Y., Betenbaugh, M.J., Bouwer, E.J. (2016) Effects of inoculum size, light intensity, and dose of anaerobic digestion centrate on growth and productivity of Chlorella and Scenedesmus microalgae and their polyculture in primary and secondary wastewater. Algal Research, 19, 278-290.

Bold, H.C., Wynne, M.J. (1978) "Introduction to the Algae. Structure and Reproduction", $2^{\text {nd }}$ ed. Prentice-Hall, Inc., Englewood Cliffs, New York, USA. 706p.

Cheah, W.Y., Show, P.L., Juan, J.C., Chang, J.S., Ling, T.C. (2018) Enhancing biomass and lipid productions of microalgae in palm oil mill effluent using carbon and nutrient supplementation. Energy Conversion and Management, 164, 188-197.

Christi, Y. (2007) Biodiesel from microalgae. Biotechnology Advances, 25, 294-306.

Chu, Z.S., Jin, X.C., Yan, F., Zheng, S.F., Pang, Y., Zeng, Q.R. (2007) Effects of edta and iron on growth and competition of Microcystis aeruginosa and Scenedesmus quadricauda. Huanjing Kexue/ Environmental Science, 28(11), 2457-2461.

Delrue, F., Alaux, E., Moudjaoui, L., Gaignard, C., Fleury, G., Perilhou, A., Richaud, P., Petitjean, M., Sassi, J.F. (2017) Optimization of Arthrospira platensis (Spirulina) growth: From laboratory scale to pilot scale. Fermentation, 3(59), 1-14.

Derakhshandeh, M., Tezcan Un, U. (2019) Optimization of microalgae Scenedesmus sp. growth rate using a central composite design statistical approach. Biomass and Bioenergy, 122, 211-220.

Dubinsky, Z., Matsukawa, R., Karube, I. (1995) Photobiological aspects of algal mass culture. Journal of Marine Biotechnology, 2, 61-65.

El-Naggar A.H. and El-Sheekh M.M.(1998) Abolishing cadmium toxicity in Chlorella vulgaris by ascorbic acid, calcium, glucose and reduced glutathione. Environmental Pollution, 101(2), 169-174.

EL-Sheekh M.M., Bedaiwy Y.M., Osman E.M., Ismail M.M. (2012) Mixotrophic and heterotrophic growth of some microalgae using extract of fungal-treated wheat bran. International Journal of Recycling of Organic Waste in Agriculture, 1, 12. 
El-Sheekh, M.M., Abou-El-Souod, G.W., El Asrag, H.A. (2018) Biodegradation of some dyes by the green alga Chlorella vulgaris and The Cyanobacterium Aphanocapsa elachista. Egyptian Journal Botany, 58(3), 1-10.

Gouveia, L., Oliveira, A.C. (2009) Microalgae as a raw material for biofuels production. Journal of Industrial Microbiology and Biotechnology, 36, 269-274.

Grobbelaar, J.U. (1994) Turbulence in mass algal cultures and the role of light/dark fluctuations. Journal of Applied Phycology, 6(3), 331-335.

Guillard, R.R.L., Sieracki, M.S. (2005) Counting cells in cultures with the light microscope. In: "Algal Culturing Techniques", pp. 239-252. Andersen R.A. (Ed.), Elsevier Academic Press, London.

Hamouda, D.R., Yeheia, D.D.S., Hussein, M.H., Hamzah, H.A. (2016) Removal of heavy metals and production of bioethanol by green alga Scenedesmus obliquus grown in different concentrations of Wastewater. Sains Malaysiana, 45(3), 467-476.

Han, F., Pei, H., Hu, W., Song, M., Ma, G., Pei, R. (2015) Optimization and lipid production enhancement of microalgae culture by efficiently changing the conditions along with the growth-state. Energy Conversion and Management, 90, 315-322.

He, H.Z., Li, H.B., Chen, F. (2005) Determination of vitamin $\mathrm{B} 1$ in seawater and microalgal fermentation media by high-performance liquid chromatography with fluorescence detection. Analytical and Bioanalytical Chemistry, 383, 875-879.

He, Q., Yang, H., Hu, C., (2015) Optimizing light regimes on growth and lipid accumulation in Ankistrodesmus fusiformis $\mathrm{H}^{1}$ for biodiesel production. Bioresource Technology, 198, 876-883.

Hu, Q., Sommerfeld, M., Jarvis, E., Ghirardi, M., Posewitz, M., Seibert, M., Darzins, A.1., (2008) Microalgal triacylglycerols as feedstocks for biofuel production: perspective and advances. The Plant Journal, 54, 621-639.

Ilavarasi, A., Mubarakali, D., Praveenkumar, R., Baldev, E., Thajuddin, N. (2011) Optimization of various growth media to freshwater microalgae for biomass production. Biotechnology, 10(6), 540545 .
Iqbal, M., Zafar, S. (1993) Effects of photon flux density, $\mathrm{CO} 2$, aeration rate, and inoculum density on growth and extracellular polysaccharide production by Porphyridium cruentum. Folia Microbiologica, 38(6), 509-514.

Juneja, A., Ceballos, R.M., Murthy, G.S. (2013) Effects of Environmental factors and nutrient availability on the biochemical composition of algae for biofuels production: A review. Energies, 6(9), 4607-4638.

Khalid, A.A.H., Yaakob, Z., Sheikh Abdullah, S.R., Takriff, M.S. (2019) Analysis of the elemental composition and uptake mechanism of Chlorella sorokiniana for nutrient removal in agricultural wastewater under optimized response surface methodology (RSM) conditions. Journal of Cleaner Production, 210, 673-686.

Kuhl, A., Lorenzen, H. (1964) Handling and culturing of Chlorella. In: "Methods in Cell Physiology", D.M. Prescott (Ed.), 1, pp. 152-187. Academic Press, New York and London.

Lee, Y.Y., Iyer, P., Torget, R.W. (1999) Dilute-acid hydrolysis of lignocellulosic biomass. Advances in Biochemical Engineering and Biotechnology, 65, 93-115.

Li, Y., Horsman, M., Wu, N., Lan, C.Q., Dubois-Calero, N. (2008) Biofuels from microalge. Biotechnology Progress, 24, 815-820.

Loftus, S.E., Johnson, Z.I. (2019) Reused cultivation water accumulates dissolved organic carbon and uniquely influences different marine microalgae. Frontiers in Bioengineering and Biotechnology, 7(101) 1- 13. https://doi.org/10.3389/ fbioe.2019.00101.

Mackinney, G. (1941) Absorption of light by chlorophyll solutions. Journal of Biological Chemistry, 140(2), 315-322.

Makarevičienė, V., Andrulevičiūtè, V., Skorupskaitė, V., Kasperovičienè, J. (2011) Cultivation of Microalgae Chlorella sp. and Scenedesmus sp. as a Potentional Biofuel Feedstock. Environmental Research, Engineering and Management, 3(57), 21-27.

Mata, T.M., Martins, A.A., Caetano, N.S. (2010) Microalgae for biodiesel production and other 
applications: A review. Renewable and Sustainable Energy Reviews, 14, 217-232.

Mercado, J.M., Sánchez-Saavedra, M.P., Correa-Reyes, J.G., Lubián, L., Montero, O., Figueroa, F.L. (2004) Blue light effect on light absorption characteristics and photosynthesis of five benthic diatom species. Aquatic Botany, 78, 265-277.

McAlice, B.J. (1971) Phytoplankton sampling with the Sedgwick-Rafter cell. Limnology and Oceanography, 16(1), 19-28.

Moreno-Garcia, L., Adjallé, K., Barnabé, S., Raghavan, G. (2017) Microalgae biomass production for a biorefinery system: Recent advances and the way towards sustainability. Renewable and Sustainable Energy Reviews, 76, 493-506.

Nigam, P.S., Singh, A. (2011) Production of liquid biofuels from renewable resources. Progress in Energy and Combustion Science, 37(1), 52-68.

Prescott, G.W. (1984) "How to Know the Freshwater Algae". $3^{\text {rd }}$ ed. Wm. C. Brown Company Publication, Iowa, USA. 384p.

Pulz, O., Grass, W. (2004) Valuable products from biotechnology of microalgae. Applied Microbiology and Biotechnology, 65(6), 635-648.

Richmond, A., Grobbelaar, J.U. (1986) Factors affecting the output rate of Spirulina platensis with reference to mass cultivation. Biomass, 10, 253-264.

Rocha, J.M.S., Garcia, J.E.C., Henriques, M.H.F. (2003) Growth aspects of the marine microalga Nannochloropsis gaditana. Bimolecular Engineering, 20, 237-242.

Ruen-ngam, D. (2017) Optimal condition for cultivation of Scenedesmus armatus cultivation and antioxidant activity of its Extract. Journal of Food Technology, Siam University, 12(1), 59-70.

Senger, H., Fleischhacker, P.H. (2006) Adaptation of the photosynthetic apparatus of Scenedesmus obliquus to strong and weak light conditions: Differences in pigments, photosynthetic capacity, quantum yield and dark reactions. Physiologia Plantarum, 40, 3542.

Sharma, R., Singh, G.P., Sharma, V.K. (2011) Comparison of different media formulation on growth, morphology and chlorophyll content of green algae, Chlorella vulgaris. International Journal of Pharma and Bio. Sciences, 2(2), 509516.

Sharma, R., Singh, G.P., Sharma, V.K. (2012) Effects of culture conditions on growth and biochemical profile of Chlorella vulgaris. Journal of Plant Pathology and Microbiology, 3(5), 1-6.

Stein, J. (1973) "Handbook of Phycological Methods. Culture Methods and Growth Measurements". Cambridge University Press. 448p.

Suganya, T., Varman, M., Masjuki, H., Renganathan, S. (2016) Macroalgae and microalgae as a potential source for commercial applications along with biofuels production: A biorefinery approach. Renewable and Sustainable Energy Reviews, 55, 909-941.

Van-Khanh, N., Diem, N.T., Nhan, L.T.T., Cu, P.V., Van, T.Q.K., Hoan, N.T. (2017) The effects of nutritional media and initial cell density on the growth and development of Spirulina platensis. Journal of Agricultural Science and Technology A and $B$ \& Hue University Journal of Science, 7, 6067. Doi: 10.17265/2161-6256/2017.10.008S.

Vymazal, J. (1995) "Algae and Element Cycling in Wetlands". CRC Press, Inc., Boca Raton, Florida, USA. 689p.

Wahidin, S., Idris, A., Shaleh, S.R.M. (2013) The influence of light intensity and photoperiod on the growth and lipid content of microalgae Nannochloropsis sp. Bioresource Technology, 129, 7-11.

Weise, T., Reinecke, J.M., Schuster, S., Pfaff, M. (2019) Optimizing turbidostatic microalgal biomass productivity: A combined experimental and coarsegrained modelling approach. Algal Research, 39, 101439: 1-9. doi:10.1016/j.algal.2019.101439.

Welter, C., Schwenk, J., Kanani, B., Van Blargan, J., Belovich, J.M. (2013) Minimal medium for optimal growth and lipid production of the microalgae Scenedesmus dimorphus. Environmental Progress and Sustainable Energy, 32(4), 937-945.

Wen, Z.Y., Chen, F. (2003) Heterotrophic production of eicosapentaenoic acid by microalgae. Biotechnology Advances, 21, 273-294. 
Yamagishi, T. (1992) "Plankton Algae in Taiwan (Formosa)". Uchida Rokakuku, Tokyo, Japan. $253 \mathrm{p}$.

Yoo, C., Jun, S.Y., Lee, J.Y. Ahn, C.Y., Oh, H.M. (2010) Selection of microalgae for lipid production under high levels carbon dioxide. Bioresource Technology, 101(1), S71-S74.
You, T., Barnett, S.M. (2004) Effect of light quality on production of extracellular polysaccharides and growth rate of Porphyridium cruentum. Biochemical Engineering Journal, 19, 251-258.

Zhao, B., Su, Y. (2014) Process effect of microalgalcarbon dioxide fixation and biomass production: A review. Renewable and Sustainable Energy Reviews, 31, 121-132.

\section{تقييم وسط النمو الأمثل وتأثير شدة الإضاءة المختلفة على النمو و التمثيل الضوئي

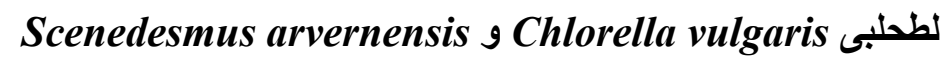

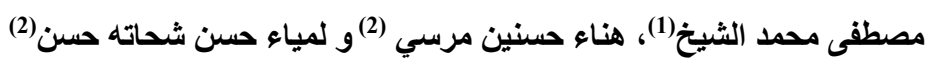

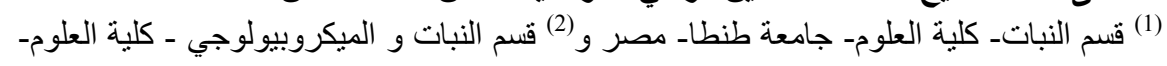 \\ جامعة المنوفية- مصر.}

Chlorella vulgaris

استخدام واسع في مختلف التطبيقات. كما يمكن استخدامها كمو اد خام في إنتاج الطاقة الحيوية، و في تغذية

الأحياء المائية، في المستحضر ات الصيدلانية، مستحضر ات التجميل، الأسمدة الحيوية، التحلل الحيوي للنفايات

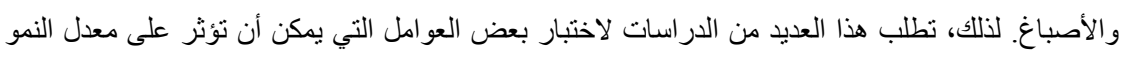

وتقييم عائدها. خلال هذه الدراسة تم بحث تأثير الأوساط الغذائية المختلفة: BBM) Bold's basal)

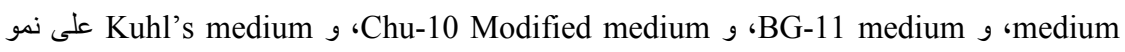

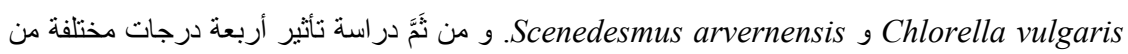

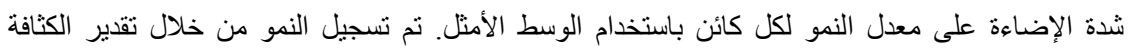
البصرية (OD) ، عد الخلايا (CC) ومحتوى الكلوروفيل. و أظهرت النتائج أن الحد الأقصى للنمو نم تسجيله

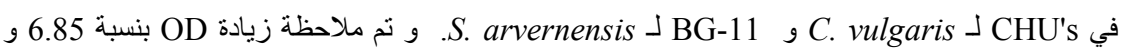

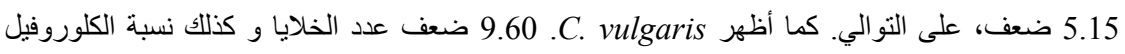
7.96 ضعف. وأوضحت النتائج زيادة عدد الخلايا لل 5. S. arvernensis 10.42 ضعف وزاد الكلوروفيل 5.90 ضعف. أظهرت تجربة شدة الإضاءة أن C. vulgaris أعطى أفضل معدل نمو تحت تأثير ثلاثة

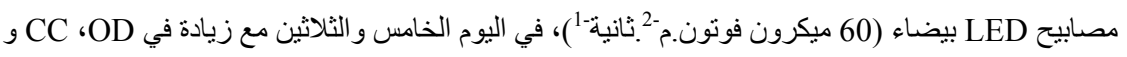

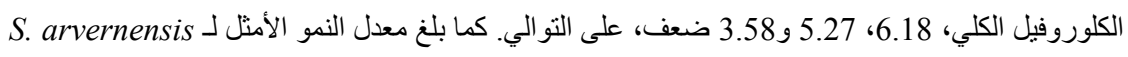
بعد التحضين في اثثين من مصابيح LED بيضاء (40 ميكرون فوتونات.م-2. ثنانية-1) ، في اليوم 35 مع زيادة

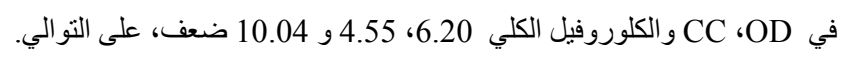

